\title{
Alteration of lipid fatty acid profile and cationic fluxes in ventricular cardiomyocytes from $\omega 3$-depleted rats
}

\author{
SÉBASTIEN PELTIER ${ }^{1}$, KARIM LOUCHAMI ${ }^{2}$, YING ZHANG $^{2}$, LAURENCE PORTOIS $^{1}$, \\ MIRJAM HACQUEBARD $^{1}$, WILLY J. MALAISSE ${ }^{2}$ and YVON A. CARPENTIER $^{1}$ \\ Laboratories of ${ }^{1}$ Experimental Surgery, ${ }^{2}$ Experimental Hormonology, \\ Université Libre de Bruxelles, B-1070 Brussels, Belgium
}

Received April 23, 2009; Accepted June 11, 2009

DOI: 10.3892/ijmm_00000238

\begin{abstract}
The bolus intravenous injection of a medium-chain triglyceride:fish oil emulsion was recently found to increase within $60 \mathrm{~min}$ the cell phospholipid content in long-chain polyunsaturated $\omega 3$ fatty acids and, hence, proposed as a potential tool to prevent cardiac arrhythmia in subjects with a decreased dietary intake of such fatty acids. In the present study, ventricular cardiomyocytes from second generation rats depleted in $\omega 3$ fatty acids were found to display the same changes in the phospholipid fatty acid pattern as that previously documented in the cardiac muscle and endothelium of such rats, altered ${ }^{86} \mathrm{Rb}$ and ${ }^{45} \mathrm{Ca}$ fluxes with emphasis on a decrease in both $\mathrm{K}^{+}$inflow and $\mathrm{K}^{+}$content and an increase in both $\mathrm{Ca}^{2+}$ inflow and content. The alteration of $\mathrm{K}^{+}$inflow could not be attributed to a decrease in ouabain-sensitive $\mathrm{Na}^{+}, \mathrm{K}^{+}$-ATPase activity as measured in cell homogenates. The cationic alterations were corrected, in part at least, by the prior intravenous injection of the medium-chain triglyceride:fish oil emulsion $60 \mathrm{~min}$ before sacrifice of the $\omega 3$-depleted rats.
\end{abstract}

\section{Introduction}

Sudden death provoked by cardiac arrhythmia remains the cause of most deaths in industrialized societies. As reviewed by Carpentier and Hacquebard (1), a rapid supply of longchain polyunsaturated $\omega 3$ fatty acids with resulting prompt incorporation of these fatty acids in cell phospholipids may offer the perspective to reduce the risk of cardiac arrhythmia including ventricular fibrillation. In this respect, administration to healthy male subjects of a novel medium-chain

Correspondence to: Professor Willy J. Malaisse, Laboratory of Experimental Hormonology, Université Libre de Bruxelles, 808 Route de Lennik, B-1070 Brussels, Belgium

E-mail:malaisse@ulb.ac.be

Key words: ventricular cardiomyocytes, long-chain polyunsaturated $\omega 3$ fatty-acid-depleted rats, medium-chain triglyceride:fish oil emulsion triglyceride:fish oil (8:2, w:v) emulsion (MCT:FO), containing $20 \%$ lipids $(\mathrm{w} / \mathrm{v})$ and injected as a $50 \mathrm{ml}$ intravenous bolus was indeed found to increase within $60 \mathrm{~min}$ and for at least $240 \mathrm{~min}$ the eicosapentaenoate content of platelet and leukocyte phospholipids (2), without any alteration of hemostatic variables (3). Preclinical investigations conducted in second-generation $\omega 3$-depleted rats have also documented, within 60 min after the intravenous injection of the same emulsion $(1.0 \mathrm{ml})$, both changes in the fatty acid pattern of heart phospholipids and triacylglycerols (4) and improvement of post-ischemic cardiac function (5), as well as remodelling of cationic fluxes in aortic rings (6). Moreover, when either normal or diabetic rats were examined $20 \mathrm{~h}$ after injection of the same emulsion $(1.0 \mathrm{ml})$, protection of aortic endothelial function against the deleterious effect of oxidized LDL was observed in experiments conducted ex vivo (7).

The present study affords information on the perturbation of lipid fatty acid pattern and cationic fluxes in ventricular cardiomyocytes from second-generation $\omega 3$-depleted rats and the partial to total correction of such defects in ${ }^{86} \mathrm{Rb}^{+}$and ${ }^{45} \mathrm{Ca}^{2+}$ handling resulting from the prior intravenous injection of the MCT:FO emulsion one hour before sacrifice.

\section{Materials and methods}

Animal model. The present study was carried out in accordance with the principles of the Animal Experimentation Ethics Committee of Brussels Free University Medical School (Belgium). Animals were housed in an animal quarter with control of temperature $\left(24^{\circ} \mathrm{C}\right)$, hygrometry $(60 \%)$ and brightness/darkness cycle $(12 \mathrm{~h} / 12 \mathrm{~h})$. Two groups of animals were used for this study. The first group (control animals) was composed of 21 male Wistar rats $(16 \pm 1$ weeks old, $426 \pm 13$ g body wt.; Iffa Credo, l'Arbresle, France) fed a commercially available chow diet (AO3; SAFE, Villemoissonsur-Orge, France). The second group of 46 male Wistar rats (20 \pm 1 weeks old, $515 \pm 13$ g body wt.; UMR 1019 INRA, Université d'Auvergne, Clermont-Ferrand, France) was fed a diet deficient in long-chain polyunsaturated $\omega 3$ fatty acids ( $\omega 3)$. The animals were issued from two generations of rats fed the w3-deficient diet (8). The difference between these two diets is described elsewhere (9). Briefly, the control and w3-depleted diet contained $5 \%$ (wt/wt) lipids from soya and sunflower, 
respectively, with the $\mathrm{C} 18: 3 \omega 3$ ponderal percentage in fatty acids being 25 times lower in the latter than in the former diet. All animals had ad libitum access to food and water.

Lipid emulsions. MCT:FO and MCT:OO lipid emulsions were manufactured respectively by Grifols (Barcelona, Spain) and B. Braun Melsungen AG (Melsungen, Germany). MCT:FO contained $80 \%$ medium chain-triacylglycerols and $20 \%$ fish oil with $0.4 \%(\mathrm{w} / \mathrm{v}) \alpha$-tocopherol. In control MCT:OO emulsion, fish oil was replaced by triolein (10).

Preparation of adult rat ventricular myocytes. The animals were anesthetized by intra-peritoneal injection of pentobarbital sodium (50 mg. $\mathrm{kg}^{-1}$ body wt.). Some $\omega 3$-depleted rats were injected via the left saphenous vein $60 \mathrm{~min}$ before heart removal with $1.0 \mathrm{ml}$ of either MCT:FO or MCT:OO emulsion. These rats are referred to as $\omega 3 \mathrm{D}-\mathrm{FO}$ and $\omega 3 \mathrm{D}-\mathrm{OO}$ rats, as distinct from $\omega 3 \mathrm{D}-\mathrm{NI}$ rats for the uninjected $\omega 3$ depleted animals. A rapid thoracotomy was then realized and the heart was quickly removed and immediately immersed in a large volume of cold $\left(4^{\circ} \mathrm{C}\right) \mathrm{Ca}^{2+}$-free Ringer solution composed of (in mM) NaCl 117, $\mathrm{KCl} 5.7, \mathrm{NaHCO}_{3} 4.4$, $\mathrm{KH}_{2} \mathrm{PO}_{4} 1.5, \mathrm{MgCl}_{2}$ 1.7, D-glucose 11.1, creatine 10.0, taurine 20.0 and HEPES 21.0, adjusted to $\mathrm{pH} 7.1$ with $\mathrm{NaOH}$ at room temperature. Rapidly, the hearts were mounted on the cannula of a Langendorff apparatus and perfused retrogradedly at a constant flow of $6 \mathrm{ml} \cdot \mathrm{min}^{-1}$ and at $37^{\circ} \mathrm{C}$ by the $\mathrm{Ca}^{2+}$-free Ringer solution during $4 \mathrm{~min}$ followed by $1 \mathrm{~h}$ of perfusion at $4 \mathrm{ml} \cdot \mathrm{min}^{-1}$ with the dissociation solution. For this enzymatic dissociation solution, $1.0 \mathrm{mg} \cdot \mathrm{ml}^{-1}$ collagenase A (Roche, Mannheim, Germany), $300 \mu \mathrm{M}$ EGTA and $\mathrm{CaCl}_{2}$ (to obtain a free $\mathrm{Ca}^{2+}$ concentration of $\sim 20 \mu \mathrm{M}$ ) were added to the $\mathrm{Ca}^{2+}$-free Ringer solution. The perfusion fluids were continuously oxygenated with $95 \% \mathrm{O}_{2}-5 \% \mathrm{CO}_{2}$. At the end of the dissociation period, the ventricles were separated from atria, chopped finely and agitated gently to dissociate individual cells in the $\mathrm{Ca}^{2+}$-free Ringer solution supplemented with $\mathrm{CaCl}_{2}$ (free $\mathrm{Ca}^{2+}$ concentration $\left.20-25 \mu \mathrm{M}\right)\left(37^{\circ} \mathrm{C}, \mathrm{pH} 7.1\right.$, solution I). The resulting cell suspension was filtered through a mesh with a pore size of $220 \mu \mathrm{m}$ and the cells were then suspended in the solution I. After an incubation period of $5 \mathrm{~min}$ at $37^{\circ} \mathrm{C}$ during which the cells were allowed to settle down, the supernatant was discarded and replaced by an appropriate volume of the solution I. Then, the cell suspension was agitated during $10 \mathrm{~min}$ at $37^{\circ} \mathrm{C}$ and the free $\mathrm{Ca}^{2+}$ concentration was progressively increased to attain $320-325 \mu \mathrm{M}$ at the end of the agitation period. Once again, the cell suspension was then incubated during $5 \mathrm{~min}$ at $37^{\circ} \mathrm{C}$ without agitation to allow the cells to sediment. The supernatant was then removed and the cells resuspended twice in the $\mathrm{Ca}^{2+}$ free Ringer solution supplemented with fatty acid-free bovine serum albumin $\left(5.0 \mathrm{mg} / \mathrm{ml}^{-1}\right)$ (Sigma, Steinheim, Germany) and $\mathrm{CaCl}_{2}$ to obtain a free $\mathrm{Ca}^{2+}$ concentration of $\sim 300 \mu \mathrm{M}$ $\left(37^{\circ} \mathrm{C}, \mathrm{pH} 7.4\right)$. Lastly, the cells were transferred in the $\mathrm{Ca}^{2+}$ free Ringer solution enriched with $\mathrm{CaCl}_{2}$ (free $\mathrm{Ca}^{2+}$ concentration $1 \mathrm{mM})$ and $1 \%$ penicillin-streptomycin $\left(37^{\circ} \mathrm{C}\right.$, $\mathrm{pH}$ 7.4). The cells were then placed in Petri dishes at $37^{\circ} \mathrm{C}$ in a tissue culture incubator with $5 \% \mathrm{CO}_{2}$ until use.
Measurement of phospholipid fatty acid pattern. The lipid fatty acid pattern of freshly isolated ventricular cardiomyocytes obtained from normal rats and $\omega 3$-depleted rats was determined by a procedure previously described $(11,12)$.

Measurement of ${ }^{86} \mathrm{Rb}^{+}$uptake. The method used to measure the net uptake of ${ }^{86} \mathrm{Rb}^{+}$was previously described (13). Briefly, $90 \mathrm{~min}$ after the end of the isolation procedure the myocytes were centrifuged $\left(100 \mathrm{x} \mathrm{g}, 3 \mathrm{~min}, 20^{\circ} \mathrm{C}\right)$, the supernatant removed and the cells resuspended in an appropriate volume of a bicarbonate- and HEPES-buffered medium containing (in $\mathrm{mM}$ ) $\mathrm{NaCl} 111$, HEPES $10, \mathrm{NaHCO}_{3} 24, \mathrm{KCl} 5, \mathrm{MgCl}_{2} 1$, $\mathrm{CaCl}_{2}$ 1, D-glucose 8.3 and $1.0 \mathrm{mg} \cdot \mathrm{ml}^{-1}$ fatty acid-free bovine serum albumin (Sigma). The cell suspension (25 $\mu 1)(\sim 50,000$ cells) was then placed in polyethylene tubes and, after addition of $25 \mu 1$ of the bicarbonate- and HEPES-buffered medium containing, when so required, $200 \mu \mathrm{M}$ ouabain, preincubated for $20 \mathrm{~min}$ at $37^{\circ} \mathrm{C}$. Then, $50 \mu 1$ of the bicarbonate and HEPES-buffered medium containing ${ }^{86} \mathrm{RbCl}\left(50 \mu \mathrm{Ci}^{-\mathrm{ml}^{-1}}\right)$ were added to each tube. After 10 or 60 min incubation at $37^{\circ} \mathrm{C}$, the tubes were centrifuged $\left(1,000 \mathrm{x} \mathrm{g}, 1 \mathrm{~min}, 4^{\circ} \mathrm{C}\right)$ and a layer $(150 \mu \mathrm{l})$ of dibutylphthalate was added. The cells were then separated from the incubation medium by centrifugation $\left(1,000 \mathrm{x} \mathrm{g}, 3 \mathrm{~min}, 4^{\circ} \mathrm{C}\right)$ and the tubes were cut so that the bottom contained cells and part of the oil layer. The radioactive content was then examined by liquid scintillation.

Measurement of ${ }^{45} \mathrm{Ca}^{2+}$ uptake. Cell suspension (25 $\left.\mu \mathrm{l}\right)$ $(\sim 50,000$ cells; see above) placed in the polyethylene tubes were mixed with $25 \mu 1$ of the bicarbonate and HEPESbuffered medium containing ${ }^{45} \mathrm{Ca}^{2+}\left(8.2 \mu \mathrm{Ci} \cdot \mathrm{ml}^{-1}\right)$. This medium contained, as required, $\mathrm{NaCl} 115 \mathrm{mM}$ and $\mathrm{KCl} 5 \mathrm{mM}, \mathrm{NaCl}$ $65 \mathrm{mM}$ and $\mathrm{KCl} 55 \mathrm{mM}$, or $\mathrm{NaCl} 5 \mathrm{mM}$ and $\mathrm{KCl} 115 \mathrm{mM}$, so that the final $\mathrm{K}^{+}$concentration of the incubation medium amounted to 5,30 or $60 \mathrm{mM}$. After 10 or $60 \mathrm{~min}$ of incubation at $37^{\circ} \mathrm{C}$, the same procedure as that used for ${ }^{86} \mathrm{Rb}^{+}$ uptake measurement was followed.

Analysis of cationic fluxes. The analysis of data was conducted as described elsewhere (14). It is based on the assumption that the time course for the net uptake of ${ }^{86} \mathrm{Rb}$ or ${ }^{45} \mathrm{Ca}(\mathrm{U})$, as a function of time ( $\mathrm{t}$, expressed as min), corresponds to the following equation: $U=U_{\max }\left(1-\mathrm{e}^{-\mathrm{Kt}}\right)$, equation in which $\mathrm{U}_{\max }$ and $\mathrm{K}$ refer, respectively, to the net uptake of the tracer under consideration at isotopic equilibrium and its fractional outflow rate from the cells (expressed as $\mathrm{min}^{-1}$ ). The fractional outflow rate was calculated from the values for the net uptake of ${ }^{86} \mathrm{Rb}$ and ${ }^{45} \mathrm{Ca}$ at min 60 , expressed relative to those recorded within the same experiment(s) at min 10. The $U_{\max }$ was then calculated from the fractional outflow rate and the mean absolute values for ${ }^{86} \mathrm{Rb}$ and ${ }^{45} \mathrm{Ca}$ net uptake recorded after 10 or 60 min incubation under the same experimental conditions. The mean values derived from these two estimations (and the deviation from mean values) were then used to assess the cationic inflow-outflow rate at isotopic equilibrium (i.e. $\mathrm{U}_{\max } \mathrm{x} \mathrm{K}$ ).

Measurement of distribution spaces. For measuring the ${ }^{3} \mathrm{H}_{2} \mathrm{O}$ and $\left[\mathrm{U}-{ }^{14} \mathrm{C}\right]$ sucrose of $\mathrm{L}-\left[1-{ }^{14} \mathrm{C}\right]$ glucose distribution spaces, 
Table I. Fatty acid pattern of phospholipids (PL) and triglycerides (TG).

\begin{tabular}{|c|c|c|c|c|}
\hline \multirow{2}{*}{$\begin{array}{l}\text { Rats } \\
\text { Lipids }\end{array}$} & \multicolumn{2}{|c|}{ Control } & \multicolumn{2}{|c|}{$\omega 3$-depleted } \\
\hline & PL & $\mathrm{TG}$ & PL & TG \\
\hline $\mathrm{C} 14: 0(\%)$ & $0.0 \pm 0.0(7)$ & $0.8 \pm 0.2(7)$ & $0.0 \pm 0.0(8)$ & $1.4 \pm 0.2(8)$ \\
\hline C16:0 (\%) & $9.1 \pm 0.2(7)$ & $20.6 \pm 0.6(7)$ & $9.5 \pm 0.1(8)$ & $21.6 \pm 1.9(8)$ \\
\hline 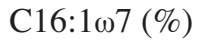 & $0.1 \pm 0.0(7)$ & $0.4 \pm 0.2(7)$ & $0.3 \pm 0.0(8)$ & $1.7 \pm 0.4(8)$ \\
\hline C18:0 (\%) & $17.8 \pm 0.2(7)$ & $8.5 \pm 0.6(7)$ & $21.1 \pm 0.4(8)$ & $4.5 \pm 1.2(8)$ \\
\hline 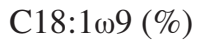 & $2.5 \pm 0.2(7)$ & $10.0 \pm 2.7(7)$ & $3.8 \pm 0.1(8)$ & $23.5 \pm 1.9(8)$ \\
\hline $\mathrm{C} 18: 2 \omega 6(\%)$ & $26.8 \pm 1.5(7)$ & $33.9 \pm 1.3(7)$ & $31.1 \pm 0.9(8)$ & $39.4 \pm 2.6(8)$ \\
\hline C20:0 (\%) & $0.3 \pm 0.0(7)$ & $0.7 \pm 0.3(7)$ & $0.3 \pm 0.0$ & $1.4 \pm 0.3(8)$ \\
\hline $\mathrm{C} 18: 3 \omega 3(\%)$ & $0.2 \pm 0.0(7)$ & $1.3 \pm 0.2(7)$ & $0.0 \pm 0.0(8)$ & $0.0 \pm 0.0(8)$ \\
\hline 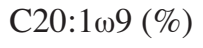 & $0.1 \pm 0.0$ & $0.1 \pm 0.1(7)$ & $0.1 \pm 0.0(8)$ & $0.0 \pm 0.0(8)$ \\
\hline $\mathrm{C} 20: 2 \omega 6(\%)$ & $0.3 \pm 0.0$ & $0.5 \pm 0.2(7)$ & $0.2 \pm 0.0(8)$ & $0.2 \pm 0.1(8)$ \\
\hline C20:3w6 (\%) & $0.2 \pm 0.0$ & $0.0 \pm 0.0$ & $0.0 \pm 0.0$ & $0.0 \pm 0.0(8)$ \\
\hline C22:0 (\%) & $0.2 \pm 0.0$ & $0.0 \pm 0.0(7)$ & $0.4 \pm 0.0$ & $0.0 \pm 0.0(8)$ \\
\hline 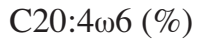 & $21.6 \pm 0.6(7)$ & $8.1 \pm 0.9(7)$ & $30.1 \pm 0.5(8)$ & $0.0 \pm 0.0(8)$ \\
\hline $\mathrm{C} 22: 1 \omega 9(\%)$ & $0.2 \pm 0.0(7)$ & $0.0 \pm 0.0(7)$ & $0.1 \pm 0.0(8)$ & $0.0 \pm 0.0(8)$ \\
\hline C20:5w3 (\%) & $0.1 \pm 0.0(7)$ & $0.0 \pm 0.0(7)$ & $0.0 \pm 0.0(8)$ & $0.0 \pm 0.0(8)$ \\
\hline C24:0 (\%) & $0.1 \pm 0.0(7)$ & $0.0 \pm 0.0(7)$ & $0.2 \pm 0.0(1)$ & $0.0 \pm 0.0(8)$ \\
\hline 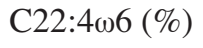 & $0.5 \pm 0.0(7)$ & $0.7 \pm 0.2(7)$ & $1.8 \pm 0.1(8)$ & $1.8 \pm 0.5(8)$ \\
\hline $\mathrm{C} 22: 5 \omega 3(\%)$ & $2.3 \pm 0.1(7)$ & $2.6 \pm 0.5(7)$ & $0.1 \pm 0.0(8)$ & $0.0 \pm 0.0(8)$ \\
\hline C22:6w3 (\%) & $17.5 \pm 1.0(7)$ & $10.3 \pm 1.4(7)$ & $0.8 \pm 0.1(8)$ & $0.0 \pm 0.0(8)$ \\
\hline
\end{tabular}

$25 \mu 1$ of the bicarbonate- and HEPES-buffered medium containing tracer amounts of ${ }^{3} \mathrm{H}_{2} \mathrm{O}$ and either $\left[\mathrm{U}_{-}{ }^{14} \mathrm{C}\right]$ sucrose or $\mathrm{L}-\left[1-{ }^{14} \mathrm{C}\right]$ glucose mixed with $2.0 \mathrm{mM}$ of the unlabelled corresponding sugar were added to $25 \mu \mathrm{l}$ cell suspension. The tubes were then incubated during $5 \mathrm{~min}$ at $37^{\circ} \mathrm{C}$ and the procedure described above was again followed.

$\mathrm{Na}^{+}, \mathrm{K}^{+}$-ATPase activity. The assay or $\mathrm{Na}^{+}-\mathrm{K}^{+}$-ATPase was conducted in $60 \mu \mathrm{l}$ of cardiomyocyte homogenates, these samples contained $1.22 \pm 0.10 \mu \mathrm{g}$ DNA $(\mathrm{n}=20)$, with a mean DNA content of $73.2 \pm 12.1 \mathrm{pg}$ DNA/cell $(n=20)$. For such a purpose, frozen cardiomyocytes stored at $-80^{\circ} \mathrm{C}$ were defrosted and sonicated on ice thrice for $10 \mathrm{sec}$. After removal of an aliquot part for DNA dosage, the sonicates were centrifuged at $4^{\circ} \mathrm{C}$ and $13,000 \mathrm{x}$ g for $30 \mathrm{~min}$, the supernatant being then diluted in a $1: 3$ ratio with a histidine- $\mathrm{HCl}$ buffer $(\mathrm{pH} 7.2)$ containing $20 \mathrm{mM}$ histidine, $6 \mathrm{mM} \mathrm{MgCl}_{2}, 20 \mathrm{mM} \mathrm{KCl}$, $80 \mathrm{mM} \mathrm{NaCl}$ and $20 \mathrm{mM} \mathrm{NaN}_{3}$. Cell homogenate $(60 \mu \mathrm{l})$ was mixed with $100 \mu \mathrm{l}$ of a $1.0 \mathrm{mM}$ ATP solution (also prepared in the histidine- $\mathrm{HCl}$ buffer) and $40 \mu \mathrm{l}$ of the same buffer containing, when so required, $12 \mathrm{mM}$ ouabain. After $30 \mathrm{~min}$ incubation at $37^{\circ} \mathrm{C}$, the reaction was halted by heating for $10 \mathrm{~min}$ at $70^{\circ} \mathrm{C}$. The resulting reaction mixture was stored at $-20^{\circ} \mathrm{C}$, and eventually examined for its inorganic phosphate content. In the 1-10 and 10-100 nmol/sample range, the inorganic phosphate standards yielded rectilinear absorbance/ concentration relationships.

Presentation of results. All results are expressed as mean values $( \pm$ SEM) together with the number of individual determinations (n) or degree of freedom (df). The statistical significance of differences between mean values was assessed by use of Student's t-test.

\section{Results}

Fatty acid pattern of cardiomyocyte lipids. Phospholipids. In the cardiomyocytes from $\omega 3$-depleted rats, the phospholipid fatty acid pattern displayed several anomalies, tightly resembling those previously documented in the heart of comparable rats (4).

First, at variance with the situation found in control animals, no $\mathrm{C} 18: 3 \omega 3$ and $\mathrm{C} 20: 5 \omega 3$ was detected in the phospholipids of $\omega 3$-depleted rats. The weight percentage of $\mathrm{C} 22: 5 \omega 3$ and $\mathrm{C} 22: 6 \omega 3$ was one order of magnitude lower in the latter rats than in control animals (Table I).

The $\mathrm{C} 22: 6 \omega 3 / \mathrm{C} 22: 5 \omega 3$ ratio was also significantly lower $(\mathrm{p}<0.02)$ in the $\omega 3$-depleted rats than in the control animals, suggesting facilitated generation of $\mathrm{C} 22: 5 \omega 3$ from $\mathrm{C} 22: 6 \omega 3$ in the former rats (Table II).

Second, the weight percentage of the three major longchain polyunsaturated $\omega 6$ fatty acids in phospholipids

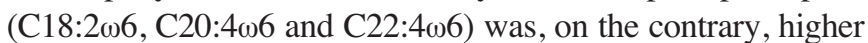
$(\mathrm{p}<0.03$ or less) in the $\omega 3$-depleted rats than in the control

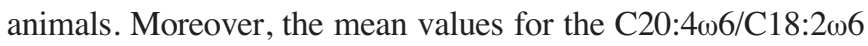
and $C 22: 4 \omega 6 / C 20: 4 \omega 6$ ratios were also higher in the $\omega 3$ depleted rats than in control animals. Such a difference failed to achieve statistical significance $(\mathrm{p}<0.08)$ in the case of the $\mathrm{C} 20: 4 \omega 6 / \mathrm{C} 18: 2 \omega 6$ ratio, but was highly significant $(\mathrm{p}<0.001)$ in the case of the $\mathrm{C} 22: 4 \omega 6 / \mathrm{C} 20: 4 \omega 6$ ratio. These findings thus suggest facilitated generation of $\mathrm{C} 20: 4 \omega 6$ and $\mathrm{C} 22: 4 \omega 6$ from their respective precursors in the $\omega 3$-depleted rats. 
Table II. Paired ratio between distinct fatty acids in the phospholipids.

\begin{tabular}{lll}
\hline Rats & \multicolumn{1}{c}{ Control } & w3-depleted \\
\hline $\mathrm{C} 22: 6 \omega 3 / \mathrm{C} 22: 5 \omega 3$ & $7.65 \pm 0.15(7)$ & $6.05 \pm 0.51(8)$ \\
$\mathrm{C} 20: 4 \omega 6 / \mathrm{C} 18: 2 \omega 6$ & $0.83 \pm 0.07(7)$ & $0.98 \pm 0.04(8)$ \\
$\mathrm{C} 22: 4 \omega 6 / \mathrm{C} 20: 4 \omega 6\left(\mathrm{x} 10^{3}\right)$ & $23.9 \pm 2.1(7)$ & $59.5 \pm 2.3(8)$ \\
$\mathrm{C} 16: 1 \omega 7 / \mathrm{C} 16: 0\left(\mathrm{x} 10^{3}\right)$ & $12.9 \pm 1.1(7)$ & $32.3 \pm 1.2(8)$ \\
$\mathrm{C} 18: 1 \omega 9 / \mathrm{C} 18: 0$ & $0.139 \pm 0.011(7)$ & $0.185 \pm 0.006(8)$ \\
$\mathrm{C} 18: 0 / \mathrm{C} 16: 0$ & $1.97 \pm 0.04(7)$ & $2.23 \pm 0.06(8)$ \\
$\mathrm{C} 20: 0 / \mathrm{C} 18: 0\left(\mathrm{x} 10^{3}\right)$ & $15.0 \pm 0.8(7)$ & $13.0 \pm 0.5(8)$ \\
$\mathrm{C} 22: 0 / \mathrm{C} 20: 0$ & $0.84 \pm 0.03(7)$ & $1.40 \pm 0.04(8)$ \\
$\mathrm{C} 24: 0 / \mathrm{C} 22: 0$ & $0.53 \pm 0.00(7)$ & $0.44 \pm 0.02(8)$ \\
$\mathrm{C} 20: 1 \omega 9 / \mathrm{C} 18: 1 \omega 9\left(\mathrm{x} 10^{3}\right)$ & $33.3 \pm 2.3(7)$ & $29.2 \pm 4.1(6)$ \\
$\mathrm{C} 22: 1 \omega 9 / \mathrm{C} 20: 1 \omega 9$ & $1.81 \pm 0.34(7)$ & $1.58 \pm 0.16(5)$ \\
\hline
\end{tabular}

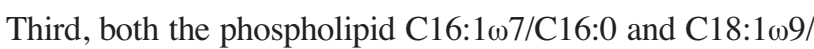
$\mathrm{C} 18: 0$ ratios were higher $(\mathrm{p}<0.005$ or less) in $\omega 3$-depleted rats than in control animals, suggesting increased activity of $\Delta 9$-desaturase.

Fourth, as judged from the C18:0/C16:0 and C22:0/C20:0 ratio, the elongation of the concerned fatty acids was favoured $(\mathrm{p}<0.01$ or less) in the $\omega 3$-depleted rats. A mirror image prevailed, however, in the case of the C20:0/C18:0 ( $<<0.05)$ and $\mathrm{C} 24: 0 / \mathrm{C} 22: 0(\mathrm{p}<0.005)$ ratio.

Last, when considering the pathway leading to the generation of nervonic acid, the $\mathrm{C} 18: 1 \omega 9 / \mathrm{C} 18: 0$ ratio was, as already mentioned, higher $(\mathrm{p}<0.005)$ in the $\omega 3$-depleted rats than in the control animals. However, such was no more the case for the $\mathrm{C} 20: 1 \omega 9 / \mathrm{C} 18: 1 \omega 9$ and $\mathrm{C} 22: 1 \omega 9 / \mathrm{C} 20: 1 \omega 9$ ratios, which, even if ignoring null values found in the $\omega 3$-depleted rats, remained lower, albeit not significantly so $(\mathrm{p}>0.3$ or more), in the latter rats than in control animals.

Triglycerides. The total fatty acid content of triglycerides, expressed relative to that of phospholipids failed to differ significantly $(\mathrm{p}>0.3)$ in control rats $(56.0 \pm 8.4 \mu \mathrm{g} / \mathrm{mg} ; \mathrm{n}=7)$ and $\omega 3$-depleted rats $(67.2 \pm 8.0 \mu \mathrm{g} / \mathrm{mg} ; \mathrm{n}=8)$.

However, the fatty acid pattern of triglycerides differed in several respects when comparing $\omega 3$-depleted rats to control animals.

First, whilst sizeable amounts of $\mathrm{C} 18: 3 \omega 3, \mathrm{C} 22: 5 \omega 3$ and $\mathrm{C} 22: 6 \omega 3$ were present in the control animals, none of these long-chain polyunsaturated $\omega 3$ fatty acids was detected in any $\omega 3$-depleted rats (Table I).

Second, in sharp contrast to the situation found in phospholipids, the amount of long-chain polyunsaturated $\omega 6$ fatty acids in the triglycerides was about thrice lower $(\mathrm{p}<0.007)$ in $\omega 3$-depleted rats $\left(33.6 \pm 5.5 \mu \mathrm{g} / 10^{6}\right.$ cells; $\left.\mathrm{n}=8\right)$ than in control animals $\left(90.9 \pm 17.9 \mu \mathrm{g} / 10^{6}\right.$ cells; $\left.\mathrm{n}=7\right)$. As a matter of fact, the mean value for the triglyceride content of each long-chain polyunsaturated $\omega 6$ fatty acid (C18:2 $\omega 6, \mathrm{C} 18: 3 \omega 6, \mathrm{C} 20: 2 \omega 6$,

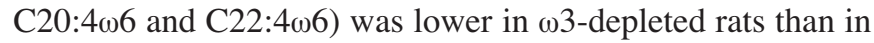
control animals (Table III). Such a difference achieved statistical significance for the two most abundant $\omega 6$ fatty

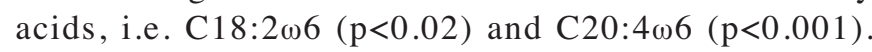

Table III. Absolute values $\left(\mu \mathrm{g} / 10^{6}\right.$ cells $)$ for the triglyceride content in long-chain polyunsaturated $\omega 6$ fatty acids.

\begin{tabular}{|c|c|c|c|}
\hline Rats & Control & $\omega 3$-depleted & $\mathrm{P}$ \\
\hline C18:2 $\omega 6$ & $70.73 \pm 13.68(7)$ & $31.81 \pm 4.97(8)$ & $<0.02$ \\
\hline $\mathrm{C} 18: 3 \omega 6$ & $0.90 \pm 0.73(7)$ & $0.00 \pm 0.00(8)$ & $<0.21$ \\
\hline $\mathrm{C} 20: 2 \omega 6$ & $1.31 \pm 0.59(7)$ & $0.22 \pm 0.18$ & $<0.09$ \\
\hline$C 20: 4 \omega 6$ & $16.26 \pm 3.65(7)$ & $0.00 \pm 0.00(8)$ & $<0.001$ \\
\hline $\mathrm{C} 22: 4 \omega 6$ & $1.67 \pm 0.64(7)$ & $1.55 \pm 0.51(8)$ & $<0.90$ \\
\hline All & $90.87 \pm 17.92(7)$ & $33.58 \pm 5.46(8)$ & $<0.007$ \\
\hline
\end{tabular}

Nevertheless, the overall efficiency of the metabolism of long-chain polyunsaturated fatty acids, as judged from the $\mathrm{C} 22: 4 \omega 6 / \mathrm{C} 18: 2 \omega 6$ ratio, was higher $(\mathrm{p}<0.04)$ in $\omega 3$-depleted rats $\left(59.9 \pm 10.5 \times 10^{-3} ; \mathrm{n}=6\right)$ than in control animals $\left(29.9 \pm 2.9 \times 10^{-3} ; \mathrm{n}=5\right)$.

Third, the $\mathrm{C} 16: 1 \omega 7 / \mathrm{C} 16: 0$ ratio whenever not yielding a null value, was almost twice higher $(\mathrm{p}<0.006)$ in $\omega 3$-depleted rats $\left(98.7 \pm 5.4 \times 10^{-3} ; n=6\right)$ than in control animals $\left(56.5 \pm 1.3 \times 10^{-3}\right.$; $\mathrm{n}=2$ ). Likewise, even if ignoring both 2 samples from control animals, in which no C18:1 19 could be detected, and 3 samples from $\omega 3$-depleted rats, in which the C18:0 content of triglycerides did not exceed $0.68 \pm 0.65 \mu \mathrm{g} / 10^{6}$ cells, the $\mathrm{C} 18: 1 \omega 9$ / $\mathrm{C} 18: 0$ ratio remained twice higher $(\mathrm{p}<0.05)$ in the $\omega 3$-depleted rats $(3.86 \pm 0.76 ; n=5)$ than in the control animals $(1.83 \pm 0.33$; $\mathrm{n}=5)$.

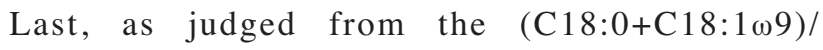
$(\mathrm{C} 16: 0+\mathrm{C} 16: 1 \omega 7)$ ratio, the elongase activity was not significantly different $(\mathrm{p}>0.1)$ in the $\omega 3$-depleted rats $(1.21 \pm 0.18$; $\mathrm{n}=8)$ and control animals $(0.83 \pm 0.14 ; \mathrm{n}=7)$.

Diglycerides. Sizeable amounts of diglycerides were found in 5 out of 7 control animals and 7 out of $8 \omega 3$-depleted rats, with overall mean values for the diglyceride/phospholipid fatty acid content of $4.19 \pm 1.25 \mu \mathrm{g} / \mathrm{mg}(\mathrm{n}=7)$ in the former animals and $5.66 \pm 0.89 \mu \mathrm{g} / \mathrm{mg}(\mathrm{n}=8)$ in the latter rats.

When present in detectable amounts, the diglyceride content in C22:6 63 averaged 4.10 $\pm 0.94 \mu \mathrm{g} / 10^{6}$ cells $(\mathrm{n}=3)$ in the cardiomyocytes from control animals. This was the sole long-chain polyunsaturated $\omega 3$ fatty acids detected in the diglycerides of these animals. No long-chain polyunsaturated $\omega 3$ fatty acid was detected in the diglycerides of $\omega 3$-depleted rats (Table IV).

Among the long-chain polyunsaturated $\omega 6$ fatty acids,

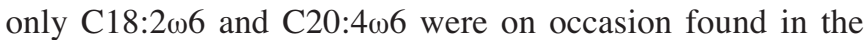
diglycerides of control rats, with mean respective values of $6.89 \pm 2.60$ and $3.24 \pm 0.55 \mu \mathrm{g} / 10^{6}$ cells ( $\mathrm{n}=5$ in both cases). Only C18:2 $\omega 6$ was detected in 7 out $8 \omega 3$-depleted rats with a mean value $2.62 \pm 0.46 \mu \mathrm{g} / 10^{6}$ cells. The diglyceride total content in long-chain polyunsaturated $\omega 6$ fatty acids was thus lower $(\mathrm{p}<0.02)$ in the $\omega 3$-depleted rats than in the control animals $\left(10.13 \pm 3.11 \mu \mathrm{g} / 10^{6}\right.$ cells; $\left.\mathrm{n}=5\right)$, a situation comparable to that found in triglycerides.

Sizeable amount of C16:0, C18:0 and C18:1 $\omega 9$ were, on occasion, also found in both control animals and $\omega 3$-depleted rats, in which they averaged respectively $3.62 \pm 0.23 \mu \mathrm{g} / 10^{6}$ 
Table IV. Fatty acid pattern of diglycerides (DG) and unesterified fatty acids (UFA).

\begin{tabular}{|c|c|c|c|c|}
\hline \multirow{2}{*}{$\begin{array}{l}\text { Rats } \\
\text { Lipids }\end{array}$} & \multicolumn{2}{|c|}{ Control } & \multicolumn{2}{|c|}{$\omega 3$-depleted } \\
\hline & DG & UFA & DG & UFA \\
\hline $\mathrm{C} 16: 0\left(\mu \mathrm{g} / 10^{6}\right.$ cells $)$ & $3.62 \pm 0.23(5)$ & $2.65 \pm 0.41(7)$ & $2.71 \pm 0.43(7)$ & $4.08 \pm 2.60(3)$ \\
\hline C18:0 $\left(\mu \mathrm{g} / 10^{6}\right.$ cells $)$ & $3.80 \pm 0.70(5)$ & $4.08 \pm 0.45(7)$ & $2.07 \pm 0.31(7)$ & $4.18 \pm 2.51(4)$ \\
\hline 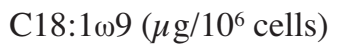 & $1.71 \pm 0.12(3)$ & $1.53(1)$ & $1.43 \pm 0.39(4)$ & $1.76 \pm 0.12(3)$ \\
\hline 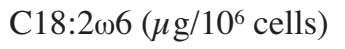 & $6.89 \pm 0.26(5)$ & $2.59 \pm 0.23(6)$ & $2.62 \pm 0.46(7)$ & $1.85 \pm 0.36(5)$ \\
\hline $\mathrm{C} 20: 4 \omega 6\left(\mu \mathrm{g} / 10^{6}\right.$ cells $)$ & $3.24 \pm 0.55(5)$ & $2.20 \pm 0.05$ (3) & $0.84(1)$ & N.D. \\
\hline $\mathrm{C} 22: 6 \omega 3\left(\mu \mathrm{g} / 10^{6}\right.$ cells $)$ & $4.10 \pm 0.94(3)$ & $2.69 \pm 0.44(3)$ & N.D. & N.D. \\
\hline
\end{tabular}

N.D., never detected.

Table V. Distribution spaces.

\begin{tabular}{lll}
\hline Rats & \multicolumn{1}{c}{ Control } & w3-depleted \\
\hline${ }^{3} \mathrm{HOH}(\mathrm{pl} / \mathrm{cell})$ & $18.50 \pm 1.95(21)$ & $19.67 \pm 0.95(115)$ \\
{$\left[\mathrm{U}-{ }^{14} \mathrm{C}\right]$ sucrose $(\mathrm{pl} / \mathrm{cell})$} & $7.27 \pm 0.83(21)$ & \\
$\mathrm{L}-\left[1-{ }^{14} \mathrm{C}\right]$ glucose $(\mathrm{pl} / \mathrm{cell})$ & & $8.84 \pm 0.74(115)$ \\
Intracellular space (pl/cell) & $11.23 \pm 1.23(21)$ & $10.83 \pm 0.40(115)$ \\
$\begin{array}{l}\text { Extracellular space } \\
\left(\%{ }^{3} \mathrm{HOH} \text { space }\right)\end{array}$ & $38.6 \pm 2.0(21)$ & $37.9 \pm 1.8(115)$ \\
\hline
\end{tabular}

cells $(\mathrm{n}=5)$ and $2.71 \pm 0.43 \mu \mathrm{g} / 10^{6}$ cells $(\mathrm{n}=7)$ in the case of C16:0, 3.80 $\pm 0.70 \mu \mathrm{g} / 10^{6}$ cells $(\mathrm{n}=5)$ and $2.07 \pm 0.31 \mu \mathrm{g} / 10^{6}$ cells $(\mathrm{n}=7)$ in the case of $\mathrm{C} 18: 0$, and $1.71 \pm 0.12 \mu \mathrm{g} / 10^{6}$ cells $(\mathrm{n}=3)$ and $1.43 \pm 0.39 \mu \mathrm{g} / 10^{6}$ cells $(\mathrm{n}=4)$ in the case of $\mathrm{C} 18: 1 \omega 9$. The values recorded in the $\omega 3$-depleted rats for these 3 fatty acids thus only represented $68.9 \pm 7.6 \% \quad(n=18$, $\mathrm{p}<0.01)$ of the corresponding mean values found in control animals $(100.0 \pm 7.1 \% ; n=18)$. The mean paired $C 18: 1 \omega 9 /$ C18:0 ratio was higher, albeit not significantly so $(\mathrm{p}>0.2)$, in $\omega 3$-depleted rats $(0.656 \pm 0.166 ; n=4)$ than in control animals $(0.393 \pm 0.049 ; n=3)$.

Unesterified fatty acids. Whether expressed as $\mu \mathrm{g} / 10^{6}$ cells or relative to the fatty acid content of phospholipids the total amount of unesterified fatty acids found in the cardiomyocytes failed to differ significantly ( $p>0.14$ or more) in control animals and $\omega 3$-depleted rats, with overall mean values of $8.40 \pm 1.88 \mu \mathrm{g} / 10^{6}$ cells and $3.96 \pm 1.20 \mu \mathrm{g} / \mathrm{mg}(\mathrm{n}=15$ in both cases).

The sole long-chain polyunsaturated $\omega 3$ fatty acids found, on occasion, and solely in a few control animals (3 out of 7 animals), was $\mathrm{C} 22: 6 \omega 3$, which averaged in these 3 control animals $2.69 \pm 0.44 \mu \mathrm{g} / 10^{6}$ cells (Table IV).

Among the long-chain polyunsaturated $\omega 6$ fatty acids,

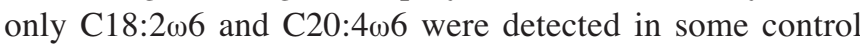
animals, in which they averaged respectively $2.59 \pm 0.23 \mu \mathrm{g} / 10^{6}$ cells $(\mathrm{n}=6)$ and $2.20 \pm 0.05 \mu \mathrm{g} / 10^{6}$ cells $(\mathrm{n}=3)$. In the $\omega 3$-depleted

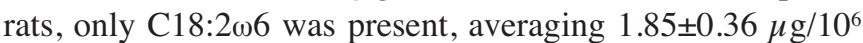
cells $(n=5)$. The total amount of long-chain polyunsaturated $\omega 6$ fatty acids was thus twice higher $(\mathrm{p}<0.02)$ in control animals $\left(3.69 \pm 0.49 \mu \mathrm{g} / 10^{6}\right.$ cells; $\left.\mathrm{n}=6\right)$ than in $\omega 3$-depleted rats. This finding is comparable to those made in triglycerides and diglycerides.

The two other sole unesterified fatty acids found in the cardiomyocytes of most control animals were C16:0 $\left(2.65 \pm 0.41 \mu \mathrm{g} / 10^{6}\right.$ cells; $\left.\mathrm{n}=7\right)$ and C18:0 (4.08 $\pm 0.45 \mu \mathrm{g} / 10^{6}$ cells; $n=7)$. The corresponding values in $\omega 3$-depleted rats were $4.08 \pm 2.60 \mu \mathrm{g} / 10^{6}$ cells $(\mathrm{n}=3)$ for $\mathrm{C} 16: 0$ and 4.18 $\pm 2.51 \mu \mathrm{g} / 10^{6}$ cells $(n=4)$ for $C 18: 0$. The $\mathrm{C} 18: 0 / \mathrm{C} 16: 0$ ratio averaged $1.63 \pm 0.12(n=7)$ and $1.61 \pm 0.35(n=3)$ in the control animals and $\omega 3$-depleted rats, respectively.

Cell volume and extracellular space. As shown in Table V, after $5 \mathrm{~min}$ incubation at $37^{\circ} \mathrm{C}$, the ${ }^{3} \mathrm{HOH}$ distribution space and that of the extracellular markers $\left(\left[\mathrm{U}-{ }^{14} \mathrm{C}\right]\right.$ sucrose or L$\left[1-{ }^{14} \mathrm{C}\right]$ glucose) were not significantly different in control and $\omega 3 \mathrm{D}$ rats. Such was also the case for the intracellular space, taken as the difference between the ${ }^{3} \mathrm{HOH}$ and extracellular spaces. In the light of these findings, no correction was made for extracellular contamination in the further analysis of the measurements for ${ }^{45} \mathrm{Ca}$ and ${ }^{86} \mathrm{Rb}$ net uptake. Nevertheless, it should be kept in mind that such an extracellular contamination was not negligible. For instance, when considering the basal results for ${ }^{86} \mathrm{Rb}$ uptake recorded after $60 \mathrm{~min}$ incubation of cells from control rats, the extracellular and intracellular amounts of the radioactive tracer, expressed as $\mathrm{K}^{+}$equivalent, yielded respective values $36.4 \pm 4.2$ and $508.8 \pm 35.1 \mathrm{fmol} / \mathrm{cell}$, the latter value corresponding to an apparent intracellular $\mathrm{K}^{+}$concentration of $45.3 \pm 3.1 \mathrm{mM}$ (d.f.=60). Likewise, the basal results for ${ }^{45} \mathrm{Ca}$ uptake after 60 min incubation of cells from control rats yielded respective extracellular and intracellular amounts of $7.3 \pm 0.8$ and $24.2 \pm 3.2 \mathrm{fmol} / \mathrm{cell}$, the latter value corresponding to an apparent intracellular $\mathrm{Ca}^{2+}$ concentration of $2.2 \pm 0.3 \mathrm{mM}$ (d.f.=53).

${ }^{86} \mathrm{Rb}$ net uptake. Under the present experimental conditions, preincubation for $20 \mathrm{~min}$ at $37^{\circ} \mathrm{C}$ in the presence of $0.1 \mathrm{mM}$ ouabain followed by $10-60 \mathrm{~min}$ incubation at $37^{\circ} \mathrm{C}$ in the presence of $0.05 \mathrm{mM}$ ouabain failed to cause marked changes in ${ }^{86} \mathrm{Rb}$ net uptake (Table VI). For instance, after $60 \mathrm{~min}$ incubation the net uptake of ${ }^{86} \mathrm{Rb}$ by cells from control rats and $\omega 3 \mathrm{D}$ rats injected with the MCT:FO emulsion averaged 
Table VI. ${ }^{86} \mathrm{Rb}$ uptake.

\begin{tabular}{|c|c|c|c|c|}
\hline Rats & Control & $\omega 3 \mathrm{D}-\mathrm{NI}$ & $\omega 3 \mathrm{D}-\mathrm{OO}$ & $\omega 3 \mathrm{D}-\mathrm{FO}$ \\
\hline \multicolumn{5}{|l|}{${ }^{86} \mathrm{Rb}$ net uptake (fmol/cell) } \\
\hline - Total & $300.1 \pm 17.2(42)$ & $97.4 \pm 7.5(34)$ & $92.5 \pm 4.6(41)$ & $135.5 \pm 9.7(43)$ \\
\hline $\min 60$ & $545.2 \pm 24.9(41)$ & $193.6 \pm 90(34)$ & $178.6 \pm 9.4(38)$ & $259.3 \pm 12.0(43)$ \\
\hline \multirow[t]{2}{*}{ - Ouabain-resistant } & $283.8 \pm 14.4(42)$ & $127.6 \pm 10.1(34)$ & $93.1 \pm 5.1(37)$ & $129.4 \pm 6.0(43)$ \\
\hline & $491.9 \pm 21.2(42)$ & $189.1 \pm 8.9(34)$ & $176.7 \pm 8.1(40)$ & $237.2 \pm 13.0(43)$ \\
\hline \multicolumn{5}{|l|}{${ }^{86} \mathrm{Rb}$ net uptake (\% of $\min 10$ ) } \\
\hline \multirow{2}{*}{$\begin{array}{ll}- \text { Total } & \min 10 \\
& \min 60\end{array}$} & $100.0 \pm 4.4(42)$ & $100.0 \pm 5.1(34)$ & $100.0 \pm 4.2(41)$ & $100.0 \pm 3.9(43)$ \\
\hline & $177.0 \pm 4.4(41)$ & $202.3 \pm 5.1(34)$ & $183.2 \pm 4.1(38)$ & $198.6 \pm 3.9(43)$ \\
\hline \multicolumn{5}{|l|}{${ }^{86} \mathrm{Rb}$ fractional outflow rate $\left(\mathrm{min}^{-1}\right)$} \\
\hline - Total & 0.082 & 0.067 & 0.078 & 0.068 \\
\hline \multicolumn{5}{|l|}{ Isotopic equilibrium data for total uptake } \\
\hline$-\mathrm{K}^{+}$cell content $(\mathrm{fmol} / \mathrm{cell})$ & $542.7 \pm 6.5$ & $198.2 \pm 1.1$ & $175.5 \pm 4.7$ & $269.2 \pm 5.4$ \\
\hline - $\mathrm{K}^{+}$inflow-outflow (fmol/min per cell) & $44.5 \pm 0.5$ & $13.3 \pm 0.1$ & $13.7 \pm 0.4$ & $18.3 \pm 0.4$ \\
\hline
\end{tabular}

Table VII. ${ }^{45} \mathrm{Ca}$ uptake.

\begin{tabular}{|c|c|c|c|}
\hline Rats & Control & $\omega 3 \mathrm{D}-\mathrm{NI}$ & $\omega 3 \mathrm{D}-\mathrm{FO}$ \\
\hline \multicolumn{4}{|c|}{${ }^{45} \mathrm{Ca}$ net uptake (fmol/cell at min 10$)$} \\
\hline - At $5 \mathrm{mM} \mathrm{K}^{+}$ & $14.12 \pm 1.60(27)$ & $18.03 \pm 1.66(31)$ & $9.90 \pm 1.02(32)$ \\
\hline - At $30 \mathrm{mM} \mathrm{K}^{+}$ & $22.36 \pm 1.78(26)$ & $27.39 \pm 2.10(32)$ & $21.29 \pm 1.22(32)$ \\
\hline - AT $60 \mathrm{mM} \mathrm{K}^{+}$ & $25.47 \pm 2.27(32)$ & $38.49 \pm 2.28(32)$ & $27.68 \pm 0.89(33)$ \\
\hline \multicolumn{4}{|c|}{${ }^{45} \mathrm{Ca}$ net uptake at $60 \min (\%$ of $\min 10)$} \\
\hline - At $5 \mathrm{mM} \mathrm{K}^{+}$ & $192.9 \pm 7.6(34)$ & $230.0 \pm 7.9(32)$ & $268.1 \pm 12.1(33)$ \\
\hline - At $60 \mathrm{mM} \mathrm{K}^{+}$ & $181.9 \pm 6.9(32)$ & $170.9 \pm 4.7(32)$ & $177.4 \pm 2.4(33)$ \\
\hline \multicolumn{4}{|c|}{${ }^{45} \mathrm{Ca}$ fractional outflow rate $\left(\mathrm{min}^{-1}\right)$} \\
\hline - at $5 \mathrm{mM} \mathrm{K}^{+}$ & 0.072 & 0.054 & 0.042 \\
\hline - At $60 \mathrm{mM} \mathrm{K}^{+}$ & 0.079 & 0.087 & 0.082 \\
\hline \multicolumn{4}{|c|}{ Equilibrium $\mathrm{Ca}^{2+}$ cell content (fmol/cell) } \\
\hline - At $5 \mathrm{mM} \mathrm{K}^{+}$ & $29.70 \pm 2.19$ & $42.96 \pm 0.25$ & $33.63 \pm 4.77$ \\
\hline - At $60 \mathrm{mM} \mathrm{K}^{+}$ & $46.86 \pm 0.22$ & $65.29 \pm 0.96$ & $49.71 \pm 0.26$ \\
\hline \multicolumn{4}{|c|}{ Equilibrium $\mathrm{Ca}^{2+}$ inflow-outflow (fmol/min per cell) } \\
\hline - At 5 mM K+ & $2.14 \pm 0.16$ & $2.32 \pm 0.01$ & $1.41 \pm 0.20$ \\
\hline - At $60 \mathrm{mM} \mathrm{K}^{+}$ & $3.70 \pm 0.02$ & $5.68 \pm 0.08$ & $4.08 \pm 0.02$ \\
\hline
\end{tabular}

$90.9 \pm 3.2 \%(\mathrm{n}=85 ; \mathrm{p}<0.006)$ of the mean corresponding values found after preincubation and incubation in the absence of ouabain. In the cells obtained from $\omega 3 \mathrm{D}$ rats, either uninjected or injected with the MCT:OO emulsion $60 \mathrm{~min}$ before sacrifice, such a percentage averaged $98.3 \pm 3.2 \%$ $(n=74 ; p>0.6)$. When taking into account extracellular contamination, the results recorded in the control and $\omega 3 \mathrm{D}$ FO rats indicated that, in these animals, ouabain decreased the $\mathrm{K}^{+}$cell content after 60 min incubation by no more than $10.4 \pm 0.1 \%(n=2)$.

Whether after 10 or 60 min incubation and whether in the presence or absence of ouabain, the net uptake of ${ }^{86} \mathrm{Rb}^{+}$was severely decreased $(\mathrm{p}<0.001)$ in either the $\omega 3 \mathrm{D}-\mathrm{NI}$ or $\omega 3 \mathrm{D}$ OO rats, averaging respectively $37.8 \pm 1.3 \%(n=136)$ and $33.1 \pm 0.8 \%(n=156)$ of the results found, under the same experimental conditions in control animals (100.0 $2.5 \%$; $\mathrm{n}=167)$. In the $\omega 3 \mathrm{D}-\mathrm{FO}$ rats, however, the net uptake of ${ }^{86} \mathrm{Rb}$ represented $46.6 \pm 1.3 \%(\mathrm{n}=172)$ of the control values and, as such, was significantly higher $(\mathrm{p}<0.001)$ than that recorded in either $\omega 3 \mathrm{D}-\mathrm{NI}$ or $\omega 3 \mathrm{D}-\mathrm{OO}$ rats.

Only minor differences were observed in the time course for ${ }^{86} \mathrm{Rb}$ net uptake in the four groups of rats (Table VI). The results recorded after $60 \mathrm{~min}$ incubation, when expressed relative to those recorded in the same experiments after only 


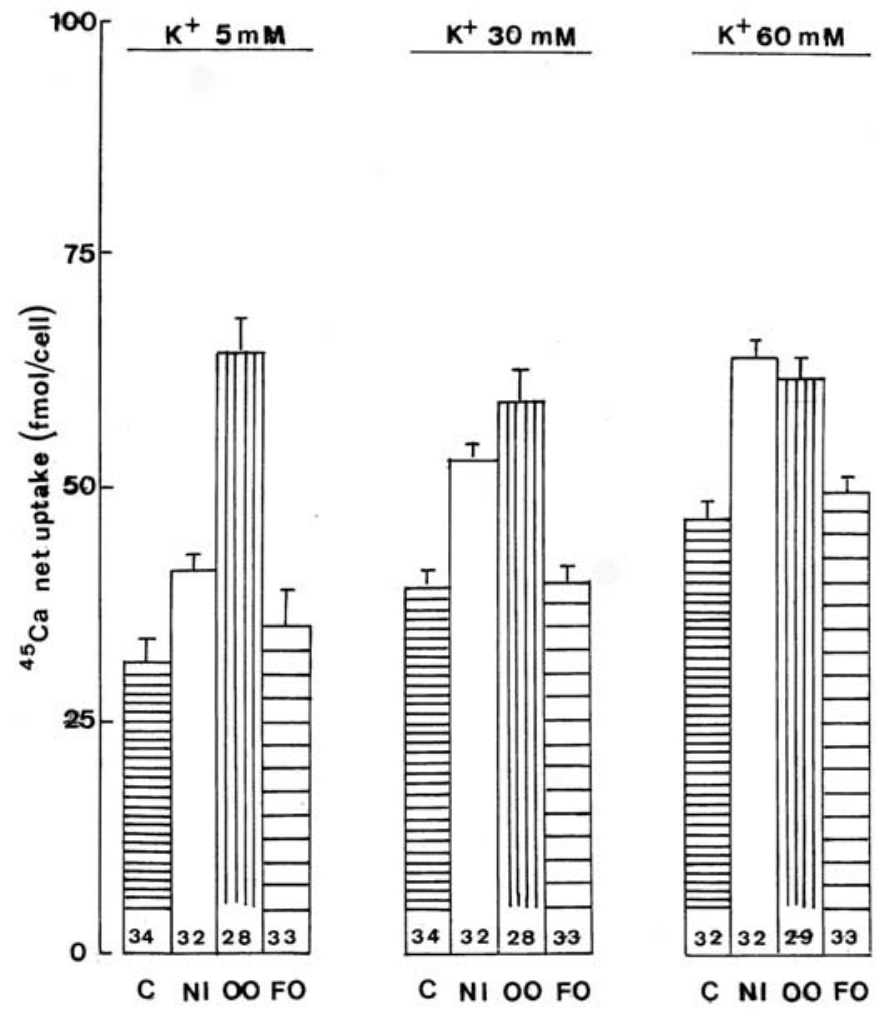

Figure 1. Mean values ( \pm SEM) for the net uptake of ${ }^{45} \mathrm{Ca}$ by cardiomyocytes from control (C), $\omega 3 \mathrm{D}-\mathrm{NI}(\mathrm{NI}), \omega 3 \mathrm{D}-\mathrm{OO}(\mathrm{OO})$ and $\omega 3 \mathrm{D}-\mathrm{FO}(\mathrm{FO})$ rats incubated for $60 \mathrm{~min}$ at increasing extracellular $\mathrm{K}^{+}$concentrations. The number of determinations is shown at the bottom of each column.

10 min incubation, averaged in the $\omega 3$-depleted rats $194.6 \pm 2.6 \%(\mathrm{n}=115)$, as distinct $(\mathrm{p}<0.001)$ from only $177.0 \pm 4.4 \%(\mathrm{n}=41)$ in the control animals. In this respect, no significant difference $(p>0.5)$ was observed between $\omega 3 \mathrm{D}-\mathrm{NI}$ and $\omega 3 \mathrm{D}-\mathrm{FO}$ rats. The difference between control rats and either $\omega 3 \mathrm{D}-\mathrm{NI}$ or $\omega 3 \mathrm{D}-\mathrm{FO}$ rats remained significant $(\mathrm{p}<0.01)$ when the SEM on both the 10 min reference data (ranging between 3.9 and $5.1 \%$ ) and the 60 min data (see above) were taken into account. Even the most pronounced difference in the time course for ${ }^{86} \mathrm{Rb}$ net uptake, i.e. that observed between control animals and $\omega 3 \mathrm{D}-\mathrm{NI}$ rats, only resulted in a modest decrease of the estimated ${ }^{86} \mathrm{Rb}$ fractional outflow rate from $0.082 \mathrm{~min}^{-1}$ in the former animals to $0.067 \mathrm{~min}^{-1}$ in the latter rats.

The just-mentioned modest difference in the ${ }^{86} \mathrm{Rb}$ fractional outflow rate was obviously not sufficient to mask the marked changes in both the cell $\mathrm{K}^{+}$content at isotopic equilibrium and corresponding $\mathrm{K}^{+}$outflow-inflow rate (Table VI). Taking into account the ${ }^{86} \mathrm{Rb}$ fractional outflow rate and the absolute values for ${ }^{86} \mathrm{Rb}$ net uptake, as measured after 10 and $60 \mathrm{~min}$ incubation, the equilibrium cell $\mathrm{K}^{+}$content averaged $543 \pm 6 \mathrm{fmol} / \mathrm{cell}$ in control rats, as distinct from $198 \pm 1$ and $175 \pm 5 \mathrm{fmol} / \mathrm{cell}$ in $\omega 3 \mathrm{D}-\mathrm{NI}$ and $\omega 3 \mathrm{D}-\mathrm{OO}$ rats and $269 \pm 5 \mathrm{fmol} /$ cells in $\omega 3 \mathrm{D}-\mathrm{FO}$ rats. Likewise, the estimated inflow-outflow rate of $\mathrm{K}^{+}$amounted to $44.5 \pm 0.5 \mathrm{fmol} / \mathrm{min}$ per cell in control rats, as compared to only $13.3 \pm 0.1$ and $13.7 \pm 0.4 \mathrm{fmol} / \mathrm{min}$ per cell in $\omega 3 \mathrm{D}-\mathrm{NI}$ and $\omega 3-\mathrm{OO}$ rats and $18.3 \pm 0.4 \mathrm{fmol} / \mathrm{min}$ per cell in $\omega 3-\mathrm{FO}$ rats. As expected from the time course for ${ }^{86} \mathrm{Rb}^{+}$net uptake, these values were higher than those derived from the net uptake of ${ }^{86} \mathrm{Rb}$ after 10 min incubation. Expressed as fmol/cell per min, the latter values indeed only represented $70.5 \pm 2.3 \%(n=160)$ of the estimated inflow-outflow rate at isotopic equilibrium. In such a respect, there was no significant difference ( $p>0.3$ or more) between the four groups of rats.

Taken as a whole, these findings indicate that the major defect of $\mathrm{K}^{+}$handling in $\omega 3$-depleted rats consists in a severe decrease in $\mathrm{K}^{+}$inflow into the cardiomyocytes. Such a decrease results in a parallel decrease of the equilibrium cell $\mathrm{K}^{+}$content. Both defects are antagonized, but not totally corrected, by the prior intravenous injection of the MCT:FO emulsion $60 \mathrm{~min}$ before sacrifice to the $\omega 3$-depleted animals.

${ }^{45} \mathrm{Ca}$ net uptake. Whether after 10 or $60 \mathrm{~min}$ incubation and whether in the presence of 5,30 or $60 \mathrm{mM}$ extracellular $\mathrm{K}^{+}$, the net uptake of ${ }^{45} \mathrm{Ca}$ was significantly higher $(\mathrm{p}<0.001)$ in the $\omega 3 \mathrm{D}-\mathrm{NI}$ and $\omega 3 \mathrm{D}-\mathrm{OO}$ rats than in control animals, averaging respectively $134.0 \pm 3.3 \%(n=191)$ and $130.8 \pm 4.3 \%(n=171)$ in the $\omega 3-\mathrm{NI}$ and $\omega 3 \mathrm{D}-\mathrm{OO}$ rats of the mean corresponding values recorded under the same experimental conditions in control animals $(100.0 \pm 3.0 \% ; \mathrm{n}=181)$. The mean percentages found in $\omega 3 \mathrm{D}-\mathrm{NI}$ and $\omega 3 \mathrm{D}-\mathrm{OO}$ rats failed to differ significantly ( $p>0.5)$ from one another. In the $\omega 3 \mathrm{D}-\mathrm{FO}$ rats, however, the mean percentage $(99.1 \pm 2.9 \% ; n=197)$ was significantly lower $(\mathrm{p}<0.001)$ than that recorded in the other $\omega 3$-depleted rats and, as a matter of fact, was virtually identical ( $p>0.8)$ to that found in the control animals (Table VII).

In all rats, the rise in extracellular $\mathrm{K}^{+}$concentration, which was osmotically compensated by an equimolar decrease in $\mathrm{Na}^{+}$concentration, resulted in an increased ${ }^{45} \mathrm{Ca}$ net uptake (Fig. 1). In the control rats and relative to the measurements made at $5 \mathrm{mM} \mathrm{K}^{+}$, the values recorded after 10 and $60 \mathrm{~min}$ incubation averaged, respectively, $159.6 \pm 10.8 \%(\mathrm{n}=26)$ and $130.3 \pm 3.2 \%(\mathrm{n}=34)$ at $30 \mathrm{mM} \mathrm{K} \mathrm{K}^{+}$and $167.0 \pm 9.5 \%(\mathrm{n}=28)$ and $157.4 \pm 4.2 \%(\mathrm{n}=32)$ at $60 \mathrm{mM} \mathrm{K} \mathrm{K}^{+}$. All these values were indeed significantly higher $(\mathrm{p}<0.001)$ than the corresponding measurements made in the same rats and at $5 \mathrm{mM} \mathrm{K}^{+}$, i.e. $100.0 \pm 10.9 \%(\mathrm{n}=27)$ after $10 \mathrm{~min}$ incubation and $100.0 \pm 3.5 \%$ $(\mathrm{n}=34)$ after $60 \mathrm{~min}$ incubation.

In the control rats and in all other animals, the mean net uptake of ${ }^{45} \mathrm{Ca}$ was lower at $30 \mathrm{mM}$ than at $60 \mathrm{mM} \mathrm{K}^{+}$, the results normalized relative to those found at $5 \mathrm{mM} \mathrm{K}^{+}$and recorded after 10 or $60 \mathrm{~min}$ incubation at $30 \mathrm{mM} \mathrm{K} \mathrm{K}^{+}$averaging $79.9 \pm 1.6 \%(n=244 ; \mathrm{p}<0.001)$ of those recorded at the same time at $60 \mathrm{mM} \mathrm{K}^{+}(100.0 \pm 1.5 \% ; \mathrm{n}=248)$.

Likewise, in the control rats and all $\omega 3$-depleted animals, the relative magnitude of the increase in ${ }^{45} \mathrm{Ca}$ net uptake caused by a rise in extracellular $\mathrm{K}^{+}$concentration was more marked after $10 \mathrm{~min}$ than after $60 \mathrm{~min}$ incubation, as expected from the fact that the depolarization of plasma membrane provoked by such a rise in $\mathrm{K}^{+}$concentration and the subsequent gating of voltage-sensitive $\mathrm{Ca}^{2+}$ affects the influx of the divalent cation into cells and, hence, is most obvious after $10 \mathrm{~min}$ incubation, i.e. at a time when the net uptake of ${ }^{45} \mathrm{Ca}$ depends mostly on the rate of $\mathrm{Ca}^{2+}$ inflow into the cardiomyocytes. As judged once again from the results normalized relative to those found at $5 \mathrm{mM} \mathrm{K}^{+}$, those recorded at 30 and $60 \mathrm{mM} \mathrm{K}^{+}$ averaged $226.5 \pm 5.0 \%(\mathrm{n}=240)$ after $10 \mathrm{~min}$ incubation, as distinct $(\mathrm{p}<0.001)$ from only $132.2 \pm 2.4 \%(\mathrm{n}=253)$ after $60 \mathrm{~min}$ incubation. 
Table VIII. $\mathrm{Na}^{+}, \mathrm{K}^{+}$-ATPase activity in cardiomyocytes (pmol/ng DNA per $30 \mathrm{~min}$ ).

\begin{tabular}{lllll}
\hline Rats & \multicolumn{1}{c}{ Normal } & $\omega 3 \mathrm{D}-\mathrm{NI}$ & $\omega 3 \mathrm{D}-\mathrm{OO}$ & $\omega 3 \mathrm{D}-\mathrm{FO}$ \\
\hline Total & $91.2 \pm 12.2(5)$ & $78.4 \pm 9.6(5)$ & $74.7 \pm 20.5(5)$ & $91.9 \pm 11.1(5)$ \\
Ouabain-resistant & $80.0 \pm 9.8(5)$ & $63.4 \pm 9.5(5)$ & $59.5 \pm 18.3(5)$ & $77.5 \pm 10.2(5)$ \\
Ouabain-sensitive & $11.3 \pm 2.4(5)$ & $15.1 \pm 1.7(5)$ & $16.1 \pm 2.5(5)$ & $14.3 \pm 1.3(5)$ \\
\hline
\end{tabular}
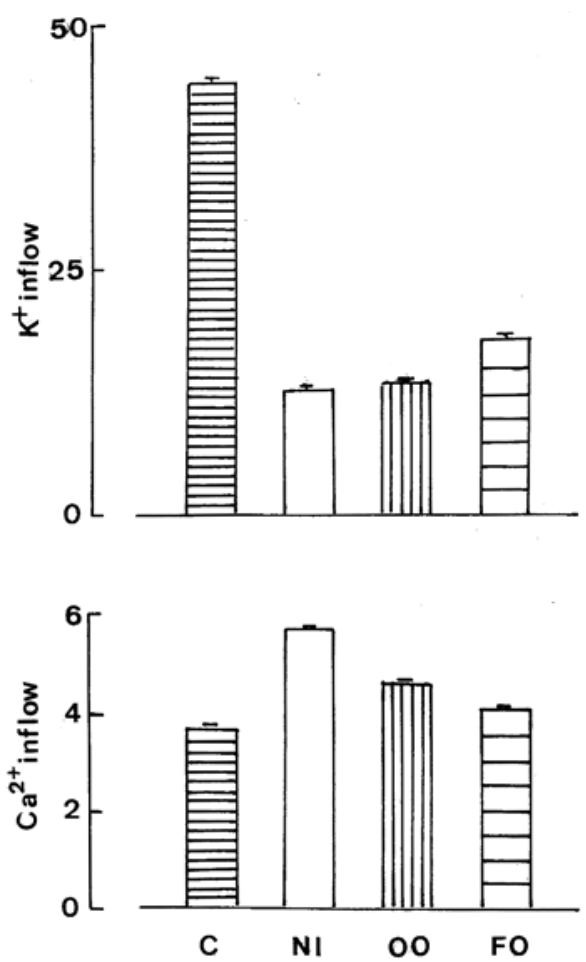

Figure 2. Basal $\mathrm{K}^{+}$inflow and $\mathrm{Ca}^{2+}$ inflow at $60 \mathrm{mM} \mathrm{K}^{+}$in cardiomyocytes from control (C), $\omega 3 \mathrm{D}-\mathrm{NI}(\mathrm{NI}), \omega 3 \mathrm{D}-\mathrm{OO}(\mathrm{OO})$ and $\omega 3 \mathrm{D}-\mathrm{FO}(\mathrm{FO})$ rats. Mean values ( \pm deviation from mean value) are expressed as $\mathrm{fmol} / \mathrm{min}$ per cell.

Relative to the net uptake of ${ }^{45} \mathrm{Ca}$ after $10 \mathrm{~min}$ incubation, that recorded after $60 \mathrm{~min}$ incubation was higher at normal extracellular $\mathrm{K}^{+}$concentration $(5 \mathrm{mM})$ than at higher $\mathrm{K}^{+}$concentrations. Little difference was found between the 4 groups of rats when the islets were incubated at $60 \mathrm{mM} \mathrm{K}^{+}$. Thus the $60 \mathrm{~min}$ values, expressed relative to the corresponding $10 \mathrm{~min}$ values, failed to differ significantly in control animals, $\omega 3 \mathrm{D}-\mathrm{NI}$ and $\omega 3 \mathrm{D}-\mathrm{OO}$ rats, and $\omega 3-\mathrm{FO}$ rats, with an overall mean value $178.9 \pm 2.3 \%(n=126)$ versus a reference value of $100.0 \pm 2.2 \%$ $(\mathrm{n}=122)$. At normal extracellular $\mathrm{K}^{+}$concentration $(5 \mathrm{mM})$, however, the $60 \mathrm{~min}$ values progressively increased from $192.9 \pm 7.6 \%(n=34)$ in control rats to $230.0 \pm 7.9 \%(n=32)$ in $\omega 3 \mathrm{D}-\mathrm{NI}$ rats and $268.1 \pm 12.1 \%(\mathrm{n}=33)$ in $\omega 3 \mathrm{D}-\mathrm{FO}$ rats. These findings imply that the fractional outflow rate of ${ }^{45} \mathrm{Ca}$ was lower in the $\omega 3 \mathrm{D}-\mathrm{NI}$ and $\omega 3 \mathrm{D}-\mathrm{FO}$ rats than in the control animals, when the cells were incubated at normal $\mathrm{K}^{+}$concentration. As shown in Table VII, such a fractional outflow rate indeed represented no more than $0.054 \mathrm{~min}^{-1}$ in the $\omega 3 \mathrm{D}$ $\mathrm{NI}$ rats and $0.042 \mathrm{~min}^{-1}$ in the $\omega 3 \mathrm{D}-\mathrm{FO}$ rats, as distinct form $0.072 \mathrm{~min}^{-1}$ in the control animals. At $60 \mathrm{mM} \mathrm{K}$, however, the ${ }^{45} \mathrm{Ca}$ fractional outflow rate was comparable in these three groups of rats, with an overall mean value $0.083 \pm 0.002 \mathrm{~min}^{-1}$ $(n=3)$.

At isotopic equilibrium, the estimated calcium content of cells exposed to 5 or $60 \mathrm{mM} \mathrm{K}^{+}$yielded $\omega 3 \mathrm{D}-\mathrm{NI} /$ control and $\omega 3 \mathrm{D}-\mathrm{FO} /$ control ratio of $142.0 \pm 2.6$ and $109.7 \pm 3.6 \%(\mathrm{n}=2$ in both cases), respectively, and an $\omega 3 \mathrm{D}-\mathrm{NI} / \omega 3 \mathrm{D}-\mathrm{FO}$ ratio of $129.5 \pm 1.8 \%(n=2)$. Such an equilibrium cell calcium content was thus significantly higher $(\mathrm{p}<0.05)$ in $\omega 3 \mathrm{D}-\mathrm{NI}$ rats than in either control of $\omega 3 \mathrm{D}-\mathrm{FO}$ rats, but not so in $\omega 3 \mathrm{D}-\mathrm{FO}$ versus control rats. The $60 \mathrm{mM} / 5 \mathrm{mM} \mathrm{K}{ }^{+}$ratio for the equilibrium cell calcium content was virtually identical, however, in these three groups of rats, with an overall mean value $152.6 \pm 2.9 \%$ $(\mathrm{n}=3)$.

Last, as estimated from the equilibrium cell calcium content and ${ }^{45} \mathrm{Ca}$ fractional outflow rate, the rate of $\mathrm{Ca}^{2+}$ inflow and outflow, at isotopic equilibrium and at $5 \mathrm{mM} \mathrm{K}^{+}$, was not significantly different ( $\mathrm{p}>0.1$ or more) in the control versus $\omega 3 \mathrm{D}-\mathrm{NI}$ or $\omega 3 \mathrm{D}-\mathrm{FO}$ rats, with an overall mean value of $1.96 \pm 0.19 \mathrm{fmol} / \mathrm{min}$ per cell $(\mathrm{n}=6)$. At $60 \mathrm{mM} \mathrm{K} \mathrm{K}^{+}$, however, such a rate remained significantly higher $(\mathrm{p}<0.01$ or less) in $\omega 3 \mathrm{D}-\mathrm{NI}$ rats $(5.68 \pm 0.08 \mathrm{fmol} / \mathrm{min}$ per cell $)$ and $\omega 3 \mathrm{D}-\mathrm{FO}$ rats $(4.08 \pm 0.02 \mathrm{fmol} / \mathrm{min}$ per cell $)$ than in control animals (3.70 $\pm 0.02 \mathrm{fmol} / \mathrm{min}$ per cell).

In summary, as judged from the data computed at isotopic equilibrium, the depletion in $\omega 3$ fatty acids fails to affect $\mathrm{Ca}^{2+}$ inflow at $5 \mathrm{mM} \mathrm{K}^{+}$, but enhances it at $60 \mathrm{mM} \mathrm{K}^{+}$. Inversely, the calcium fractional outflow rate is decreased in the cardiomycotyes of $\omega 3$-depleted rats when exposed to $5 \mathrm{mM} \mathrm{K}^{+}$, but unaffected at $60 \mathrm{mM} \mathrm{K}$. As a result of these two situations, the equilibrium cell content is invariably higher in $\omega 3 \mathrm{D}-\mathrm{NI}$ rats than in control animals, whether at 5 or $60 \mathrm{mM} \mathrm{K}^{+}$. The prior injection of the MCT:FO emulsion corrects the latter defect.

The internal consistency of this analysis is borne out by the data collected after $60 \mathrm{~min}$ incubation, i.e. close to isotopic equilibrium. Indeed, as illustrated in Fig. 1, at that time, the net uptake of ${ }^{45} \mathrm{Ca}$ averaged, in the $\omega 3 \mathrm{D}-\mathrm{NI}$ and $\omega 3 \mathrm{D}-\mathrm{OO}$ rats, $147.2 \pm 3.5 \%(\mathrm{n}=181)$ of the corresponding mean values found at the same extracellular $\mathrm{K}^{+}$concentration in the control animals $(100.0 \pm 3.3 \% ; n=100)$, whilst the $\omega 3 \mathrm{D}$ FO rats yielded a mean value of $106.5 \pm 4.5 \%$; $n=99$ ).

Likewise, there was a tight positive correlation $(\mathrm{r}=0.9961$; $\mathrm{n}=6 ; \mathrm{p}<0.001$ ) between the estimated values for $\mathrm{Ca}^{2+}$ inflowoutflow at isotopic equilibrium, as listed in Table VII, and the corresponding values for the net uptake of ${ }^{45} \mathrm{Ca}$ after $10 \mathrm{~min}$ incubation, with a paired ratio between the latter uptake (expressed as $\mathrm{fmol} / \mathrm{min}$ ) and the former estimation of $69.7 \pm 1.7 \%(n=6)$, such a percentage being consistent with the exponential pattern for the time course of ${ }^{45} \mathrm{Ca}$ net uptake, progressively tending towards its equilibrium value. 
The results obtained in the $\omega 3 \mathrm{D}-\mathrm{OO}$ rats are not listed in Table VII, because no reliable data were obtained for the time course of ${ }^{45} \mathrm{Ca}$ net uptake at $5 \mathrm{mM} \mathrm{K}$. However, at both 30 and $60 \mathrm{mM} \mathrm{K}^{+}$, the results obtained in the $\omega 3 \mathrm{D}-\mathrm{OO}$ rats were essentially comparable to those collected in $\omega 3 \mathrm{D}-\mathrm{NI}$ rats (Fig. 1). For instance, at isotopic equilibrium, the estimated calcium content of the cardiomyocytes exposed to 30 and $60 \mathrm{mM} \mathrm{K} \mathrm{K}^{+}$averaged in the $\omega 3 \mathrm{D}-\mathrm{OO}$ rats $61.4 \pm 0.7 \mathrm{fmol} / \mathrm{cell}$ $(n=4)$, as compared $(p>0.7)$ to $60.2 \pm 3.0 \mathrm{fmol} /$ cell $(n=4)$ in the $\omega 3 \mathrm{D}-\mathrm{NI}$ rats.

$\mathrm{Na}^{+}, \mathrm{K}^{+}$-ATPase. The mean total ATPase activity and that resistant to ouabain were both lower in $\omega 3 \mathrm{D}-\mathrm{NI}$ rats than in control animals and in $\omega 3 \mathrm{D}-\mathrm{OO}$ rats than in $\omega 3 \mathrm{D}-\mathrm{FO}$ rats (Table VIII). Such a difference failed however to achieve statistical significance, the readings recorded in the $\omega 3 \mathrm{D}-\mathrm{NI}$ and $\omega 3 \mathrm{D}-\mathrm{OO}$ rats, expressed relative to the mean corresponding values found in control animals and $\omega 3 \mathrm{D}-\mathrm{FO}$ rats respectively $(100.0 \pm 5.9 \% ; \mathrm{n}=20)$, averaging $80.8 \pm 8.3 \%(\mathrm{n}=20 ; \mathrm{p}<0.08)$. The absolute value for the ouabain-sensitive hydrolysis of ATP also failed to differ significantly $(p>0.15)$ in the $\omega 3 \mathrm{D}$ $\mathrm{NI}$ and $\omega 3 \mathrm{D}-\mathrm{OO}$ rats $(15.6 \pm 1.4 \mathrm{pmol} / \mathrm{ng} \mathrm{DNA} ; \mathrm{n}=10)$ versus control and $\omega 3 \mathrm{D}-\mathrm{FO}$ rats $(12.8 \pm 1.4 \mathrm{pmol} / \mathrm{mg}$ DNA; $\mathrm{n}=10)$. In the $\omega 3 \mathrm{D}-\mathrm{NI}$ and $\omega 3 \mathrm{D}-\mathrm{OO}$ it averaged $123.1 \pm 11.4 \% \quad(\mathrm{n}=10$; $\mathrm{p}>0.15$ ) of the mean corresponding values found in control animals and $\omega 3 \mathrm{D}-\mathrm{OO}$ rats, respectively $(100.0 \pm 10.8 \% ; \mathrm{n}=10)$. As expected from these findings, the ouabain-sensitive hydrolysis of ATP represented a greater fraction $(\mathrm{p}<0.01)$ of the total ATPase activity in the $\omega 3 \mathrm{D}-\mathrm{NI}$ and $\omega 3 \mathrm{D}-\mathrm{OO}$ rats $(21.6 \pm 2.1 \% ; \mathrm{n}=10)$ than in the control and $\omega 3 \mathrm{D}-\mathrm{FO}$ rats $(14.3 \pm 1.1 \% ; \mathrm{n}=10)$.

\section{Discussion}

Second generation $\omega 3$-depleted rats represent a model for the decreased dietary intake of $\omega 3$ fatty acids often prevailing in Western populations. These rats display, in addition to several features of the metabolic syndrome (15-18) decreased basal cardiac function and impaired recovery following ischemia (5).

In the present study, the ventricular cardiomyocyte phospholipids of $\omega 3$-depleted rats were found to display severe depletion of all long-chain polyunsaturated $\omega 3$ fatty acids with a low $\mathrm{C} 22: 6 \omega 3 / \mathrm{C} 22: 5 \omega 3$ ratio, increased amount of the three major long-chain polyunsaturated $\omega 6$ fatty acids (C18:2 $\omega 6$,

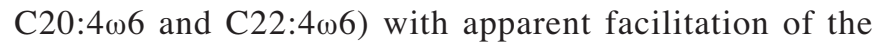
generation of $\mathrm{C} 20: 4 \omega 6$ and $\mathrm{C} 22: 4 \omega 6$ from their respective precursors, elevated $\mathrm{C} 16: 1 \omega 7 / \mathrm{C} 16: 0$ and $\mathrm{C} 18: 1 \omega 9 / \mathrm{C} 18: 0$ ratios suggesting increased activity of $\Delta 9$-desaturase, and altered generation of the precursors of nervonic acid. All these features are comparable to those previously documented in both cardiac muscle and endothelium of second generation $\omega 3$-depleted rats $(4,19)$.

These changes in the fatty acid pattern of phospholipids coincided with alteration of cationic fluxes in the ventricular cardiomyocytes prepared from $\omega 3$-depleted rats. Fig. 2 illustrates the two major anomalies in the handling of cations identified in $\omega 3$-depleted rats, namely the decrease in the basal rate of $\mathrm{K}^{+}$inflow and the increase in the rate of $\mathrm{Ca}^{2+}$ inflow observed a high extracellular $\mathrm{K}^{+}$concentration $(60 \mathrm{mM})$. Fig. 2 also illustrates that both defects were partially corrected in cardiomyocytes from $\omega 3$-depleted rats injected intravenously $60 \mathrm{~min}$ before sacrifice with the MCT:FO emulsion. The results obtained in the latter rats were indeed closer to control values ( $p<0.02$ or less) than those recorded in the $\omega 3$ depleted rats injected with the control $\omega 3$ fatty acid-poor MCT:OO emulsion.

The present findings concerning $\mathrm{K}^{+}$handling are reminiscent of those recently documented in rat pancreatic islets. Thus, in such islets, the net uptake of ${ }^{86} \mathrm{Rb}$ is also severely decreased in $\omega 3$-depleted rats. The impairment of $\mathrm{K}^{+}$inflow by an ouabain-sensitive modality, but no that mediated by an ouabain-resistant modality, is corrected by the prior intravenous administration of the MCT:FO, as distinct from MCT:OO, emulsion to the $\omega 3$-depleted rats (20).

Likewise, the islet calcium content at isotopic equilibrium is much higher in $\omega 3 \mathrm{D}-\mathrm{OO}$ rats than in control animals, whether at normal $(5 \mathrm{mM})$ or higher $(30$ and $60 \mathrm{mM})$ extracellular $\mathrm{K}^{+}$concentrations. This islet defect is also partially corrected in the $\omega 3 \mathrm{D}-\mathrm{FO}$ rats $(21)$.

The measurements of $\mathrm{Na}^{+}, \mathrm{K}^{+}$-ATPase activity in cardiomyocyte homogenates reinforce the view that the decrease of $\mathrm{K}^{+}$inflow found in intact cardiomyocytes from $\omega 3$-depleted rats is mainly attributable to alteration of an ouabain-resistant modality of $\mathrm{K}^{+}$entry into these cells. Indeed, in the cardiomyocyte homogenates, the ouabain-sensitive hydrolysis of ATP was not lower in $\omega 3 \mathrm{D}-\mathrm{NI}(\omega 3 \mathrm{D}-\mathrm{OO})$ rats than in control (or $\omega 3 \mathrm{D}-\mathrm{FO}$ ) rats, and even represented a greater fraction of the total ATPase activity in the $\omega 3 \mathrm{D}-\mathrm{NI}$ and $\omega 3 \mathrm{D}-\mathrm{OO}$ rats than in the control and $\omega 3 \mathrm{D}-\mathrm{FO}$ rats.

In conclusion, the present results extend to intact ventricular cardiomyocytes the knowledge that, in $\omega 3$-depleted rats, the perturbation of the phospholipid fatty acid coincides with alteration of cationic fluxes and that the latter alteration may be, in part at least, corrected by the intravenous injection, $60 \mathrm{~min}$ before sacrifice, of an $\omega 3$-rich medium-chain triglyceride:fish oil emulsion.

\section{Acknowledgments}

We are grateful to A. Chwalik and A. Dufour for technical assistance and to C. Demesmaeker for secretarial help. This study was supported by Convention 5459 (Project WALNUT20; Région Wallonne, Namur, Belgium).

\section{References}

1. Carpentier YA and Hacquebard M: Intravenous lipid emulsions to deliver omega 3 fatty acids. Prostaglandins Leukot Essent Fatty Acids 75: 145-148, 2006.

2. Portois L, Delckelbaum RJ, Malaisse WJ and Carpentier YA: Accumulation rapide d'eicosapentaenoate dans les phospholipides cellulaires après injection intraveineuse d'une émulsion d'huile de poisson et de triglycérides à chaîne moyenne à des sujets normaux. Nutr Clin Metabol 18 (Suppl 1): S53, 2004.

3. Pradier O, Portois L, Malaisse WJ and Carpentier YA: Hemostatic safety of the bolus intravenous injection of a novel medium-chain triglyceride:fish oil emulsion. Int J Mol Med 22: 301-307, 2008

4. Portois L, Peltier S, Sener A, Malaisse WJ and Carpentier YA: Phospholipid and triglyceride fatty acid content and pattern in the heart of rats depleted in long-chain polyunsaturated $\omega 3$ fatty acids. Nutr Res 28: 51-57, 2008. 
5. Peltier S, Malaisse WJ, Portois L, Demaison L, Novel-Chate V, Chardigny J-M, Sebedio JL, Carpentier YA and Leverve XM: Acute in vivo administration of a fish oil-containing emulsion improves post-ischemic cardiac function in $\omega 3$-depleted rats. Int J Mol Med 18: 741-749, 2006.

6. Courtois P, Louchami K, Portois L, Chardigny J-M, Sener A, Carpentier YA and Malaisse WJ: Effects of a medium-chain triglyceride:fish oil emulsion administered intravenously to $\omega 3$ fatty acid-depleted rats on cationic fluxes in aortic rings. Int J Mol Med 16: 1089-1093, 2005.

7. Fontaine D, Otto A, Portois L, Fontaine J, Berkenboom G, Malaisse WJ and Carpentier YA: Protection of aortic endothelial function in both normal and diabetic rats by intravenous bolus injection of a medium-chain triglyceride:fish oil emulsion. Int J Mol Med 18: 697-704, 2006.

8. Acar N, Chardigny J-M, Bonhomme B, Almanza S, Doly M and Sébédio JL: Long-term intake of trans (n-3) polyunsaturated fatty acids reduces the b-wave amplitude of electroretinograms in rats. J Nutr 132: 3151-3154, 2002

9. Oguzhan B, Zhang Y, Louchami K, Courtois P, Portois L, Chardigny J-M, Malaisse WJ, Carpentier YA and Sener A: Pancreatic islet function in $\omega 3$ fatty acid-depleted rats. Glucose metabolism and nutrient-stimulated insulin release. Endocrine 18: 457-466, 2006.

10. Carpentier YA, Peltier S, Portois L, Sebedio JL, Leverve X and Malaisse WJ: Rapid reduction of liver steatosis in rats injected with a novel lipid emulsion. Horm Metab Res 40: 875-879, 2008.

11. Richelle M, Carpentier YA and Deckelbaum RJ: Long- and medium-chain triacylglycerols in neutral lipid-exchange processes with human plasma low-density proteins. Biochemistry 33: 4872-4878, 1994.

12. Simoens C, Richelle M, Rössle C, Derluyn M, Deckelbaum RJ and Carpentier YA: Manipulation of tissue fatty acid profile by intravenous lipids in dogs. Clin Nutr 14: 177-188, 1995.

13. Giroix MH, Agascioglu E, Oguzhan B, Louchami K, Zhang Y, Courtois P, Malaisse WJ and Sener A: Opposite effects of Dfructose on total versus cytosolic ATP/ADP ratio in pancreatic islet cells. Biochim Biophys Acta 1757: 773-780, 2006.
14. Malaisse WJ: Assessment of inflow rate, fractional outflow rate and steady-state cellular pool of ions based on two measurements of radioactive tracer net uptake. WSEAS Transactions Biol Med 3: 317-320, 2006.

15. Armitage JA, Pearce AD, Sinclair AJ, Vingrys AJ, Weisinger RS and Weisinger HS: Increased blood pressure later in life may be associated with perinatal n-3 fatty acid deficiency. Lipids 38: 459-464, 2003.

16. Cancelas J, Prieto PG, Villanueva-Peñacarrillo ML, Zhang Y, Portois L, Sener A, Carpentier YA, Valverde I and Malaisse WJ: Glucose intolerance associated to insulin resistance and increased insulin secretion in rats depleted in long-chain polyunsaturated $\omega 3$ fatty acids. Horm Metab Res 39: 823-825, 2007.

17. Carpentier YA, Peltier S, Portois L, Sener A and Malaisse WJ: Rapid lipid enrichment in $\omega 3$ fatty acids : plasma data. Int J Mol Med 21: 355-365, 2008.

18. Oguzhan B, Sancho V, Acitores A, Villanueva-Peñacarrillo ML, Portois L, Chardigny J-M, Sener A, Carpentier YA and Malaisse WJ: Alteration of adipocyte metabolism in $\omega 3$ fatty acid-depleted rats. Horm Metab Res 38: 789-798, 2006.

19. Carpentier YA, Portois L, Louchami K, Zhang Y, Sener A and Malaisse WJ: Phospholipid and triacylglycerol fatty acid content and pattern in the cardiac endothelium of rats depleted in longchain polyunsaturated $\omega 3$ fatty acids. Cell Biochem Funct 26: 33-38, 2008.

20. Sener A, Zhang Y, Louchami K, Oguzhan B, Courtois P, Portois L, Chardigny J-M, Carpentier YA and Malaisse WJ: Alteration of $\mathrm{K}^{+}$fluxes and insulin release in pancreatic islets from $\omega 3$ fatty acid-depleted rats. Endocrine 30: 207-211, 2006.

21. Zhang Y, Oguzhan B, Louchami K, Chardigny J-M, Portois L, Carpentier YA, Malaisse WJ, Herchuelz A and Sener A: Pancreatic islet function in $\omega 3$ fatty acid-depleted rats: alteration of calcium fluxes and calcium-dependent insulin release. Am J Physiol 291: E441-E448, 2006. 